\title{
Indigenous knowledge about the greater long-nosed armadillo, Dasypus kappleri (Xenarthra: Dasypodidae), in northeastern Peru
}

\author{
DAVID W. FLECK ${ }^{\mathrm{A}}$ AND RoBert S. VOSS ${ }^{\mathrm{B}, 1}$ \\ A Division of Anthropology, American Museum of Natural History, Central Park West at 79 ${ }^{\text {th }}$ Street, New York, NY 10024, USA. \\ E-mail: dfleck@amnh.org \\ ${ }^{\text {B }}$ Division of Vertebrate Zoology (Mammalogy), American Museum of Natural History, Central Park West at $79^{\text {th }}$ Street, New York, NY 10024, USA. \\ E-mail:voss@amnh.org \\ ${ }^{1}$ Corresponding author
}

\begin{abstract}
Indigenous knowledge is a potentially important source of natural history information about unstudied species of large Amazonian mammals. The Matses, a Panoan-speaking tribe that lives in the basin of the Río Yavarí in northeastern Peru and western Brazil, retain intact traditional knowledge of the local fauna and flora. Our interviews with Matses hunters provide a rich source of original observations about Dasypus kappleri, the greater long-nosed armadillo, which we analyzed for accuracy and content by comparing items of Matses natural history information with the scientific literature. Of 66 items about this species gleaned from eight interviews, only 14 items $(21 \%)$ overlapped substantively with information in the literature, which corroborated the accuracy of 13 items ( $93 \%$ accuracy, as assessed by this method). On the single point of disagreement between the literature and our interview results, it seems highly likely that the literature is incorrect. The remaining 52 Matses observations about the natural history of $D$. kappleri contain novel information about many aspects of the behavior, diet, and predators of this large and abundant but hitherto virtually unstudied xenarthran species.
\end{abstract}

Keywords: behavior, diet, habitat, Matses, predation, reproduction

Conocimiento indígena sobre el armadillo de Kappler, Dasypus kappleri (Xenarthra: Dasypodidae), en el noreste del Perú

Resumen El conocimiento indígena es una fuente potencialmente importante de información sobre la historia natural de especies de mamíferos grandes de la Amazonía que aún no han sido estudiadas. Los Matsés, una tribu que pertenece a la familia lingüística Pano ubicada en la cuenca del río Yavarí en el noreste de Perú y el oeste de Brasil, mantienen íntegros sus conocimientos tradicionales sobre la fauna y flora de su territorio. Nuestras entrevistas con cazadores Matsés aportan un abundante repositorio de observaciones inauditas sobre Dasypus kappleri, el armadillo de Kappler, cuya exactitud analizamos comparando con la literatura científica cada punto de información sobre la historia natural proporcionada por los Matsés. De 66 puntos de información sobre esta especie extraídos de ocho entrevistas con cazadores Matsés, solamente 14 puntos $(21 \%)$ coinciden fundamentalmente con la información en la literatura, y la comparación corrobora la veracidad de 13 de estos puntos (un nivel de $93 \%$ de precisión, según este método de evaluación). El único punto de desacuerdo entre la literatura y los resultados de las entrevistas muy probablemente tiene que ver con un error en la literatura. Las restantes 52 observaciones sobre la historia natural de D. kappleri proporcionadas por los Matsés contienen información novedosa acerca de muchos aspectos del comportamiento, la dieta y los depredadores de esta gran y abundante pero hasta ahora poco estudiada especie de xenartros.

Palabras clave: comportamiento, depredación, dieta, hábitat, Matses, reproducción 


\section{INTRODUCTION}

The vast and still largely intact rainforests of western Amazonia harbor what is perhaps the most diverse mammalian fauna in the world (Voss \& Emmons, 1996). Although autecological studies of several western Amazonian primates, ungulates, and carnivorans have been undertaken in recent decades, many other mammals in the region are so elusive that they are seldom encountered by researchers. As a result, the biological literature lacks even basic natural history information about a surprising number of taxa. Indigenous Amazonians, however, often have extensive knowledge about the natural history of local mammals that are routinely hunted for meat, and this knowledge could be a productive source of biological hypotheses if there were some way to assess its reliability.

By comparing information provided by Murui (Witoto) Indians in Colombia with published results of scientific field research, Townsend (1995) found that Murui knowledge about primate natural history was, for the most part, biologically accurate. Voss \& Fleck (2011) obtained similar results working in Peru with the Matses, another society of indigenous Amazonians, who still obtain most of their dietary protein by hunting mammals. In the latter study, the authors compared Matses observations about spider monkeys (Ateles belzebuth) item-byitem with the results of primatological research on this relatively well-studied species. Of the 84 items evaluated in this way, 75\% were corroborated (in the sense that they agreed with published research results), and another $24 \%$ were judged to be plausible (not directly confirmed by scientific observations but not contradicted by any published information). Only one Matses observation about spider monkeys appeared to be problematic in light of scientifically collected data, and the discrepancy in question (concerning the sex of the dominant individual that leads foraging groups of spider monkeys) might have several alternative explanations. Such comparisons, together with others summarized by Voss \& Fleck (2011), suggest that indigenous Amazonian hunters can be accurate sources of natural history information about local game species.

Dasypus kappleri, the greater long-nosed armadillo, is a widespread but elusive large (ca. 8-12 kg) xenarthran about which surprisingly little is known. Published natural history information about D. kappleri consists almost entirely of two reports of stomach contents (Barreto et al., 1985; Szeplaki et al., 1988) and a short entry in a field guide (Emmons, 1997). Insofar as known from such sources, D. kappleri lives in primary rainforest, is nocturnal and solitary, eats invertebrates, and dens in burrows that it digs in the sides of stream banks. By contrast with most primates, the greater long-nosed armadillo has never been the focus of any scientific field study, so it would be instructive to analyze what is known of this species by indigenous Amazonian hunters as a source of novel natural history observations.

Dasypus kappleri is an important game species for the Matses, and its cultural importance is indicated by special linguistic attention, uniquely arduous hunting methods, and elaborate dietary rules. The greater long-nosed armadillo is known by several Matses names, which include a principal term (tsawes), one archaic synonym, a ceremonial term (used only in the now-discontinued komok ceremony), and three lexicalized hyponyms (names for overdifferentiated varieties; Fleck \& Voss, 2006). These armadillos are highly esteemed as food, especially in April and May (when they are very fat), and Matses hunters will spend considerable time and effort to kill one. They are hunted principally by digging and flooding them out of their burrows, a long and difficult process. Traditionally, Matses hunters hung armadillo shells on the horizontal poles of their longhouses as hunting trophies, but today this is still done only by a few old men. Several partial dietary taboos regulate how $D$. kappleri carcasses are butchered and distributed among family members, effectively ensuring that everyone in the hunter's household gets something to eat from each kill.

In this report we summarize Matses knowledge about the natural history of greater long-nosed armadillos based on recorded interviews with Matses hunters, and we compare Matses natural history observations with the scientific literature to determine what information is corroborated by previously published accounts and what information is new.

\section{MATERIALS AND METHODS}

The Matses are indigenous Panoan speakers who live along the Yavarí (Javari) River and its tributaries in northeastern Peru and western Brazil (Fleck, 2013). One of several tribes formerly known as the Mayoruna-as they are still known in Brazilthe Matses historically avoided navigable rivers and maintained hostile relations with nontribal Peruvians and Brazilians until 1969, when they were contacted by evangelical missionaries of the Summer Institute of Linguistics (Vivar, 1975). Subsequent acculturation of the Matses to the national cultures of Peru and Brazil has proceeded rapidly, but because of their recent isolation, older individuals ( $>35$ years of age) still possess undiminished traditional knowledge. Most Matses still meet all their nutritional needs through traditional subsistence activities including hunting, fishing, trapping, swidden horticulture, and collection of wild foods (Romanoff et al., 2004). Many of the younger men now speak Spanish or Portuguese at various levels of fluency, but $65-70 \%$ percent of the Matses are still essentially monolingual. 
From May to July of 1998 we elicited monologues about the natural history of local mammals from hunters from four different Peruvian Matses villages (Nuevo San Juan, Buen Peru, Buenas Lomas Antigua, Estirón), and we recorded these interviews on digital minidisks. All monologues were recorded in the Matses language. To elicit these texts, informants were asked to talk about a single mammalian taxon (e.g., a species of armadillo), which was mentioned only once by the interviewer (Fleck). Informants were asked to say as much as they liked about any topic relating to the taxon in question. Each informant's monologues were recorded with no other adults present in order to achieve independence of response. For each taxon, the interview was replicated a total of seven or eight times with different informants. These recordings were subsequently transcribed and translated by Fleck and literate Matses assistants and checked for linguistic accuracy with several other Matses speakers. The texts were then checked with speakers other than the narrators to obtain second opinions on the validity of some of the less commonly asserted natural history details. Using similar methodology, additional natural history monologues were recorded from 2010 to 2013 from a single Matses speaker as part of a language documentation project.

Our summary of Matses knowledge about the natural history of $D$. kappleri is based on eight translated interview transcripts (two from each of the four villages where we worked from 1998 to 2013), which we edited to minimize redundancy and to exclude rhetorical exhortations and extraneous narrative material. Additionally, we reorganized sentences into paragraphs with coherent topics (habitat preference, burrow construction, diet, etc.), and inserted explanatory material (in square brackets) as needed. Voucher material of D. kappleri collected in the course of this study is preserved at the Museo de Historia Natural de la Universidad Nacional Mayor de San Marcos in Lima (MUSM 11081, 11083), and at the American Museum of Natural History in New York (AMNH 268227, 268228). Plant taxa mentioned by their indigenous names in Matses interviews were identified as explained by Voss \& Fleck (2011:1112). Voucher material of palms are preserved in the herbarium of the Museo de Historia Natural de la Universidad Nacional Mayor de San Marcos and at the New York Botanical Garden.

Collection and exportation of animal and plant specimens for this project were authorized by permits issued by the Instituto Nacional de Recursos Naturales (INRENA) in Lima. Our ethnological research in Matses territory from 1998 to 1999 (when no formal tribal organization existed) was carried out at the invitation of the villages where we worked. Subsequent ethnological research (from 2010 to
2013) was conducted with the written permission of elected tribal authorities.

\section{RESULTS}

Because D. kappleri is nocturnal and the Matses did not traditionally hunt at night, much of what our interviewees had to say about the natural history of this species was inferred from spoor (tracks, feces, food remains, etc.), which the Matses are experts at interpreting. Hunters also listen carefully at burrow entrances at dawn and dusk for sounds of movement by resident animals, but knowledge of burrow architecture and nest contents was acquired more directly (by digging out burrows). Examination of stomach contents while butchering carcasses provides other information about food habits. In addition to personal experience, knowledge of armadillo natural history is also acquired from talking with other hunters, the natural history of game animals being a common topic of Matses conversation. Such communications impart shared knowledge of rarely observed behaviors that may be key to interpreting spoor and other indirect evidence.

Matses natural history information is commonly imparted by narratives, which may relate either an individual hunter's experience, or a typical day (or night) in the life of an animal. Because evidentiality is encoded grammatically in the Matses language (Fleck, 2007), recorded narratives often include relevant information about how unobserved behaviors were inferred, but such nuances are lost in translation, and the following account summarizes only the alleged factual content of our interview transcripts, which were edited and condensed as described above (see Materials and Methods). However, despite being far removed from the original source material by subsequent translation, editing, and simplification, the following composite account of the natural history of D. kappleri is, as nearly as possible, in the Matses' own words:

Greater long-nosed armadillos prefer primary upland forest. They make their burrows in the banks of stream headwater gullies, and along small streams. They forage in the dry floodplains of streams and in palm swamps (where the earth is softer), but they also root around on hilltops and hillsides. They are common in upland forest where they have not been hunted out.

Greater long-nosed armadillos always nest in burrows that they dig in the ground. Each armadillo has several active burrows and sleeps in a different one each night. There are also abandoned burrows in the vicinity of active burrows. Burrows in stream headwater gullies are deeper than burrows in stream floodplains. Each burrow has a 
large sleeping chamber, where the armadillo has its leaf bed. The leaf bed smells like armadillo urine. The burrow also has a long, narrow, blind retreat tunnel, adjacent to the sleeping chamber. The retreat tunnel is generally somewhat horizontal and has a few centimeters of water on the floor. Greater long-nosed armadillo burrows have only one entrance.

Greater long-nosed armadillos find armored millipedes [Platyrhacidae, Barydesmus sp.], round millipedes [Rhinocricidae, Neocricus sp.], centipedes, beetles, and beetle grubs in rotten logs. They root in the ground for earthworms and grubs that live in the ground. They eat any invertebrate they find. They are also very fond of isan palm [Arecaceae, Oenocarpus bataua] fruits. They eat the mesocarp of ripe isan palm fruits that fall to the ground. They also eat chukë ants that feed on the isan fruits. While eating isan palm fruit they also root in the vicinity for earthworms. They also eat the mesocarp of fallen swamp palm [Arecaceae, Mauritia flexuosa] fruits. They eat insect larvae that they find in rotten echo tree [Caricaceae, Jacaratia sp.] fruits.

The greater long-nosed armadillo is nocturnal. During the day it sleeps in its burrow. Before dusk it is awake in its burrow, rustling the dry leaves in its leaf bed, waiting for it to get dark. Right at dusk it rushes out of its burrow and then begins to travel noisily along one of its paths, which are primarily along hilltops. It stops along its path to forage, rooting for worms and grubs in soft dirt and digging into rotten logs for armored millipedes and other invertebrates. It leaves its path to root in lower ground, in the floodplains of streams or in palm swamps. If these are flooded, it roots at the edges of the flooded area. It sniffs the ground as it roots for earthworms. It follows streams as it forages, often crosses one or more streams, and then circles back to its path. It swims across deep streams. It bathes in mud holes, where collared peccaries may also bathe (during the day). It may come across one of its other burrows and check it out, but it will not sleep there if it is not yet late. When it is near dawn [between 05:00 and 05:30 in northeastern Peru] it finds its path and follows it to its nearest burrow. Once it finds its burrow, it collects fresh leaf litter to add to its bed. It leaves an area clear of leaf litter near its burrow where it does this. It rolls in its leaf bed to pack it down and may be awake in its burrow rustling the leaves in its bed for a short time after dawn. It sometimes walks around during the day in heavy rain.

Greater long-nosed armadillos are solitary. Males do not sleep with females in their burrows. They copulate when they find each other while foraging at night. The female gives birth to two offspring inside its burrow. The female eats the placenta. The young follow the mother when they are little.

White flies [small biting flies that look like light-colored mosquitoes; probably phlebotomine psychodids] live with greater long-nosed armadillos. They are always present at the entrance of active burrows. When the armadillo leaves its burrow, some flies follow it while others remain at the burrow. A burrow that is inhabited will have more white flies during the day than other, uninhabited but active burrows.

Jaguars [Panthera onca] eat greater longnosed armadillos while hunting at night. They may pounce on an armadillo from above as the armadillo passes by. Jaguars remove the carapace, and often stash a portion of the armadillo to eat later. Pumas [Puma concolor] also kill armadillos. Bush dogs [Speothos venaticus] enter armadillo burrows and follow the occupant into the blind retreat tunnel. They pull the armadillo out and eat it at the entrance of the burrow. Tayras [Eira barbara] that hunt in trios can also kill an armadillo. Black caimans [Melanosuchus niger] and anacondas [Eunectes murinus] catch armadillos as they swim across large streams.

Greater long-nosed armadillos make a low rumbling growl when disturbed. They growl loudly when a predator seizes them. Newborns whine inside the burrow.

\section{DISCUSSION}

In the left column of TABLE 1 we have broken down Matses natural history information in the composite essay presented above into 66 factual assertions. In the right column we evaluated as many of these assertions as possible based on comparisons with published research on greater long-nosed armadillos, noting which assertions are corroborated or contradicted in the literature, and which are novel. In contradictory cases, we included the conflicting published information in the right column.

Of the 66 items of Matses natural history information about D. kappleri, only 14 (about 21\%) overlap substantively with information in the scientific 
TABLE 1. Ecobehavioral information recovered from Matses monologues about greater long-nosed armadillos (Dasypus kappleri).

\begin{tabular}{|c|c|c|}
\hline & Item & Assessment \\
\hline 1. & Prefers primary upland forest & New \\
\hline 2. & Makes burrows in stream banks & Corroborated (Emmons, 1997) \\
\hline 3. & Forages in the dry floodplains of streams & Corroborated (Emmons, 1997) \\
\hline 4. & Forages in dry palm swamps & Corroborated (Emmons, 1997) \\
\hline 5. & Roots on hilltops and hillsides & New \\
\hline 6. & Common in upland forest where not hunted out & New \\
\hline 7. & Always nests in burrows dug in the ground & New \\
\hline 8. & Each armadillo has several active burrows & New \\
\hline 9. & Sleeps in a different burrow each night & New \\
\hline 10. & Abandoned burrows are near active burrows & New \\
\hline 11. & $\begin{array}{l}\text { Burrows in headwater gullies are deeper than burrows in stream } \\
\text { floodplains }\end{array}$ & New \\
\hline 12. & Burrows have a sleeping chamber 1-1.5 m deep & New \\
\hline 13. & Sleeping chamber has a leaf bed & New \\
\hline 14. & Leaf bed smells like armadillo urine & New \\
\hline 15. & Burrow has a long, narrow, blind retreat tunnel & New \\
\hline 16. & Retreat tunnel is horizontal and has water on the floor & New \\
\hline 17. & Burrows have only one entrance & Burrows have two entrances (Emmons, 1997) \\
\hline 18. & Eats armored millipedes & $\mathrm{New}$ \\
\hline 19. & Eats round millipedes & Corroborated (Barreto et al., 1985) \\
\hline 20. & Eats centipedes & Corroborated (Barreto et al., 1985; Szeplaki et al., 1988) \\
\hline 21. & Eats beetles & Corroborated (Barreto et al., 1985; Szeplaki et al., 1988) \\
\hline 22. & Eats beetle grubs & New \\
\hline 23. & Eats earthworms & Corroborated (Szeplaki et al., 1988) \\
\hline 24. & Eats chukë ants & New \\
\hline 25. & Eats other invertebrates & Corroborated (Barreto et al., 1985; Szeplaki et al., 1988) \\
\hline 26. & Eats fallen fruits of isan & New \\
\hline 27. & Eats mesocarp of fallen ripe isan fruits & New \\
\hline 28. & Eats fallen fruits of swamp palm & New \\
\hline 29. & Eats insect larvae found in rotten fruits & New \\
\hline 30. & Nocturnal & Corroborated (Emmons, 1997) \\
\hline 31. & Sleeps in burrow during the day & New \\
\hline 32. & Is awake in its burrow before dusk & $\mathrm{New}$ \\
\hline 33. & Exits burrow right at dusk & New \\
\hline 34. & Rushes out of burrow when it exits & $\mathrm{New}$ \\
\hline 35. & Begins foraging by following one of its paths & New \\
\hline 36. & Has multiple paths & Corroborated (Emmons, 1997) \\
\hline 37. & Paths are along hilltops & New \\
\hline 38. & Roots in soft earth & Corroborated (Emmons, 1997) \\
\hline 39. & Roots and digs in hollow logs & New \\
\hline 40. & Leaves its hilltop path to root in lower ground & New \\
\hline 41. & Roots at edge of flooded swamps and streams & New \\
\hline 42. & Sniffs the ground as it roots & New \\
\hline 43. & Forages following streams (when not on path) & $\mathrm{New}$ \\
\hline 44. & Crosses streams as it forages & $\mathrm{New}$ \\
\hline 45. & Swims across deep streams & New \\
\hline
\end{tabular}




\begin{tabular}{|c|c|c|}
\hline & Item & Assessment \\
\hline 46. & Bathes in mud holes used by peccaries & New \\
\hline 47. & Returns to one of its burrows at dawn & New \\
\hline 48. & Collects fresh leaf litter to add to the bed in its burrow & New \\
\hline 49. & Sometimes walks around during the day in heavy rain & New \\
\hline 50. & Solitary & Corroborated (Emmons, 1997) \\
\hline 51. & Copulates when it finds a mate while foraging at night & New \\
\hline 52. & Gives birth inside its burrow & New \\
\hline 53. & Gives birth to two offspring & Corroborated (Wetzel \& Mondolfi, 1979) \\
\hline 54. & Female eats the placenta & New \\
\hline 55. & Young follow their mother when they are little & New \\
\hline 56. & White flies present in active burrows & New \\
\hline 57. & White flies follow the armadillo as it forages & New \\
\hline 58. & Jaguars eat them as they forage at night & New \\
\hline 59. & Pumas eat them as they forage at night & New \\
\hline 60. & Bush dogs kill them by entering the burrow & New \\
\hline 61. & Tayras that hunt in trios can kill an armadillo & New \\
\hline 62. & Black caimans catch them as they swim across streams & New \\
\hline 63. & Anacondas catch them as they swim across streams & New \\
\hline 64. & Make a low grunting growl when disturbed & New \\
\hline 65. & Growl loudly when a predator seizes them & New \\
\hline 66. & Newborns whine inside the burrow & New \\
\hline
\end{tabular}

literature. Of these 14 items, 13 (about 93\%) are corroborated by scientific observations, approximately the same agreement rate that Townsend (1995) found for Murui observations about primates and that we (Voss \& Fleck, 2011) previously reported for Matses observations about spider monkeys. In effect, to the extent that Matses observations overlap with scientific observations, there is excellent agreement. The single point of disagreement between these two sources concerns the number of burrow entrances: one according to the Matses, two according to Emmons (1997). Because the Matses have extensive experience excavating $D$. kappleri from its burrows, we expect that their assertion is correct. Interestingly, Murui observations about $D$. kappleri from Amazonian Colombia also agree with the Matses on this point, "... la madriguera tiene solamente una entrada ..." (Townsend et al., 1984:47).

Almost $79 \%$ of Matses observations about $D$. kappleri address previously unrecorded aspects of its natural history, including numerous details of foraging behavior, burrow architecture, nest construction, diet, reproduction, and predation. Although some of these items are of somewhat esoteric interest (mainly to those who hunt this species for food), others suggest behavioral adaptations to avoid predation (e.g., nightly changes of burrow occupancy, rushing out of the burrow at first exit, construction of a retreat tunnel), previously unsuspected dietary habits (e.g., frugivory, also mentioned by Murui informants; Townsend et al., 1984), and entomological phenomena with implications for microbial disease transmission (if the white flies mentioned by our informants are the same phlebotomines that transmit Leishmania spp.). To the best of our knowledge, Matses information about predators of D. kappleri is entirely new, including the interesting behavior of bush dogs that enter burrows and drag captured armadillos to the surface.

There are, of course, legitimate reasons to doubt whether the Matses are entirely accurate in their interpretation of indirect evidence of nocturnal behaviors, or when they impute motives to behaviors that might have other biological interpretations. Therefore, it would be inappropriate to assert the objective truth of these ethnographic data. However, native Amazonians have only survived as successful hunters by virtue of close observation of their environment and shrewd inference from seemingly inadequate clues. In the absence of contrary indications, their accounts of the natural history of culturally important game species merit high credibility.

\section{ACKNOWLEDGEMENTS}

We are grateful, as ever, to our Matses friends and colleagues-especially Joaquín Rojas René, Fernando Shoque Uaquí Bëso, and Antonio Jiménez 
Tajur-for sharing their knowledge of the local fauna over the course of many years and hosting our many visits to Nuevo San Juan, where most of our research was conducted. Our fieldwork at Nuevo San Juan in 1998 and 1999 was partially supported by grants from the National Geographic Society and the Center for Conservation and Biodiversity at the American Museum of Natural History. A grant from the Endangered Languages Documentation Programme of the University of London School of Oriental and African Studies provided additional support for linguistic fieldwork from 2010 to 2013.

\section{REFERENCES}

Baretto, M., P. Baretto \& A. D'Alessandro. 1985. Colombian armadillos: stomach contents and infection with Trypanosoma cruzi. Journal of Mammalogy 66: 188-193. https://doi. org / $10.2307 / 1380985$

Emmons, L. H. 1997. Neotropical rainforest mammals: a field guide (2nd ed.). University of Chicago Press, Chicago. 307 pp.

Fleck, D. W. 2007. Evidentiality and double tense in Matses. Language 83: 589-614. https://doi. org / 10.1353/lan.2007.0113

Fleck, D. W. 2013. Panoan languages and linguistics. Anthropological Papers of the American Museum of Natural History 99: 1-112. https:/ / doi.org/10.5531/sp.anth.0099

Fleck, D. W. \& R. S. Voss. 2006. On the origin and cultural significance of unusually large synonym sets in some Panoan languages of western Amazonia. Anthropological Linguistics 48: 335-368.
Romanoff, S., D. M. Jiménez Huanán, F. S. Uaquí Bëso \& D. W. Fleck. 2004. Matsesën nampid chuibanaid, la vida tradicional de los Matses. Centro Amazónico de Antropología y Aplicación Práctica, Lima. 148 pp.

Szeplaki, E., J. Ochoa \& J. Clavijo A. 1988. Stomach contents of the greater long-nosed armadillo (Dasypus kappleri) in Venezuela. Mammalia 52: 422-425.

Townsend, W. R. 1995. Cultural teachings as an ecological data base: Murui (Witoto) knowledge about primates. Latinamericanist 31: 1-7.

Townsend, W. R., R. Nuñez \& V. Macuritofe R. 1984. Contribuciones a la etnozoología de la Amazonía colombiana: el conocimiento zoológico entre los Huitotos. Colombia Amazónica 2: 39-74.

Vivar, J. E. 1975. Los mayoruna: en la frontera PerúBrasil. América Indígena 35: 329-347.

Voss, R. S. \& L. H. Emmons. 1996. Mammalian diversity in Neotropical lowland rainforests: a preliminary assessment. Bulletin of the American Museum of Natural History 230: 1-115.

Voss, R. S. \& D. W. Fleck. 2011. Mammalian diversity and Matses ethnomammalogy in Amazonian Peru. Part 1: Primates. Bulletin of the American Museum of Natural History 351: 1-81. https: / / doi.org $/ 10.1206 / 351.1$

Wetzel, R. M. \& E. Mondolfi. 1979. The subgenera and species of long-nosed armadillos, genus Dasypus L. Pp. 43-63 in: Vertebrate ecology in the northern Neotropics (J. F. Eisenberg, ed.). Smithsonian Institution Press, Washington DC.

Received: 15 February 2016; Accepted: 26 March 2016 